\title{
Anti-inflammatory effects of ozonated water in an experimental mouse model
}

\author{
KAZUO AZUMA $^{1}$, TAKURO MORI ${ }^{1}$, KINYA KAWAMOTO ${ }^{1}$, KOHEI KURODA ${ }^{1}$, TAKESHI TSUKA ${ }^{1}$, \\ TOMOHIRO IMAGAWA ${ }^{1}$, TOMOHIRO OSAKI ${ }^{1}$, FUMIO ITOH ${ }^{2}$, SABURO MINAMI $^{1}$ and YOSHIHARU OKAMOTO $^{1}$ \\ ${ }^{1}$ Faculty of Agriculture, Tottori University, Tottori 680-8553; ${ }^{2}$ Sakuragawa Pump Co., Ltd., Osaka 567-0005, Japan
}

Received December 12, 2013; Accepted January 2, 2014

DOI: $10.3892 /$ br.2014.290

\begin{abstract}
Previous studies have suggested that ozonated water is safe and possesses antibacterial effects for treatment of experimental peritonitis rats. In this study, we evaluated the anti-inflammatory effects of ozonated water that was intraperitoneally injected into an experimental inflammatory mouse model. The concentrations of dissolved ozone decreased constantly and lineally, while the half-life of dissolved ozone was $36.8 \pm 2.7 \mathrm{~min}\left(27^{\circ} \mathrm{C}\right)$. The $10-\mathrm{ppm}$ ozonated water was injected intraperitoneally into mice with lipopolysaccharide (LPS)-induced acute inflammation. The results showed that the intraperitoneal injection of ozonated water decreased the levels of tumor necrosis factor- $\alpha$ (TNF- $\alpha$ ) and increased the activity of superoxide dismutase (SOD). The results suggest that ozonated water has anti-inflammatory properties and is a potential therapeutic option for acute inflammation.
\end{abstract}

\section{Introduction}

Ozone $\left(\mathrm{O}_{3}\right)$ is a triatomic molecule that contains three oxygen atoms and has a molecular weight of $47.98 \mathrm{~g} / \mathrm{mol} \mathrm{O}_{3}$ is a thermodynamically unstable molecule which, depending on system conditions such as temperature and pressure, has a short half-life and decomposes into molecular oxygen $\left(\mathrm{O}_{2}\right)(1) . \mathrm{O}_{3}$ gas is used in medicine for ozone-therapy, which involves the administration of an $\mathrm{O}_{3} / \mathrm{O}_{2}$ gas mixture (2). This $\mathrm{O}_{3} / \mathrm{O}_{2}$ mixture exhibits various effects on the immune system, such as modulating the phagocytic activity of peritoneal and alveolar macrophages $(3,4), \mathrm{O}_{3}$ increases the activity of antioxidant enzymes including glutathione peroxidase, superoxide dismutase (SOD) and catalase, thus preparing the host to face physiopathological conditions mediated by reactive oxygen species $(\operatorname{ROS})(4,5)$.

Correspondence to: Dr Yoshiharu Okamoto, Faculty of Agriculture, Tottori University, 4-101 Koyama-Minami, Tottori 680-8553, Japan

E-mail: yokamoto@muses.tottori-u.ac.jp

Key words: ozonated water, anti-inflammatory, tumor necrosis factor- $\alpha$, mouse
Findings of previous studies have shown that prolonged inhalation of $\mathrm{O}_{3}$ gas damages the respiratory system (6-12) and extrapulmonary organs $(13,14)$. A series of meta-analyses and evaluation of geographic and seasonal $\mathrm{O}_{3}$ gas-related risk has provided evidence for the association between $\mathrm{O}_{3}$ gas and mortality (15-19). As $\mathrm{O}_{3}$ inhalation is accompanied by dangerous side-effects and since $\mathrm{O}_{3}$ is a gas, its benefits are limited. To increase the effectiveness and safety of ozone treatment, ozone may be dissolved in water. This is advantageous as ozonated water is easier to administer and safer than ozone gas. However, devices to produce ozonated water, which can precisely regulate the concentration of the dissolved ozone gas are not cost effective. Therefore, ozonated water is not widely used.

Ozonated water has been shown to possess antibacterial effects $(20,21)$. Ozmen et al (22) reported that ozonated saline was effective as irrigation for treating experimental peritonitis rats. To the best of our knowledge, the side-effects of ozonated water have not yet been reported. In this study, we developed a new device to produce ozonated water, which is more cost effective than previously used devices. We also evaluated its anti-inflammatory effects on an acute inflammation experimental mouse model.

\section{Materials and methods}

Ozonated water-producing device. The ozonated waterproducing device was provided by Sakuragawa Pump Co., Ltd. (Osaka, Japan). This device can produce ozonated water from $\mathrm{O}_{2}$ and tap water and can set the concentration of the dissolved $\mathrm{O}_{3}$. The tap water used in this study contained sodium $(6.5 \mathrm{mg} / \mathrm{l})$, chloride $(6.4 \mathrm{mg} / \mathrm{l})$, calcium and magnesium $(25.4 \mathrm{mg} / \mathrm{l})$. Bacteria was not detected in the tap water. The $\mathrm{pH}$ of the tap water was 7.1. Ozonated water was used within 10 min following production.

Animals. BALB/c mice (females, 7-week-old) were purchased from CLEA Japan (Osaka, Japan). The animals were maintained under conventional conditions and used for the experiment after 7 days of acclimation. The use of these mice and the procedures were approved by the Animal Research Committee of Tottori University.

Evaluation of the protective effect of ozonated water on lipopolysaccharide (LPS)-induced acute inflammation. Mice were 


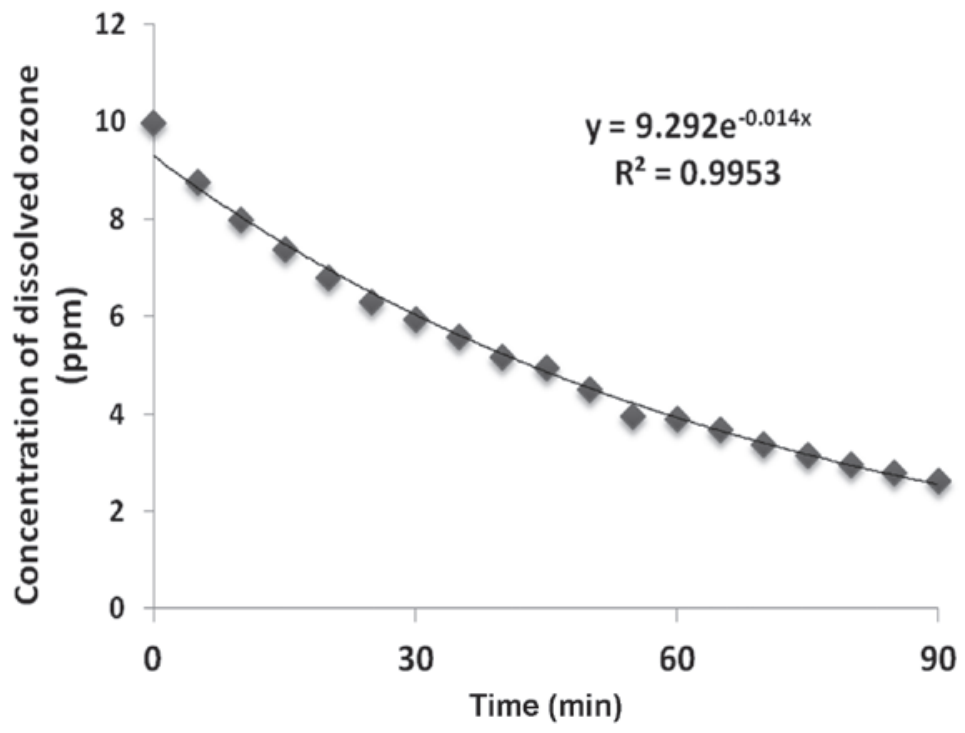

Figure 1. The half-life of dissolved ozone in ozonated water. $\mathrm{Y}$ indicates the approxiamation; $\mathrm{R}^{2}$, coefficient of determination.

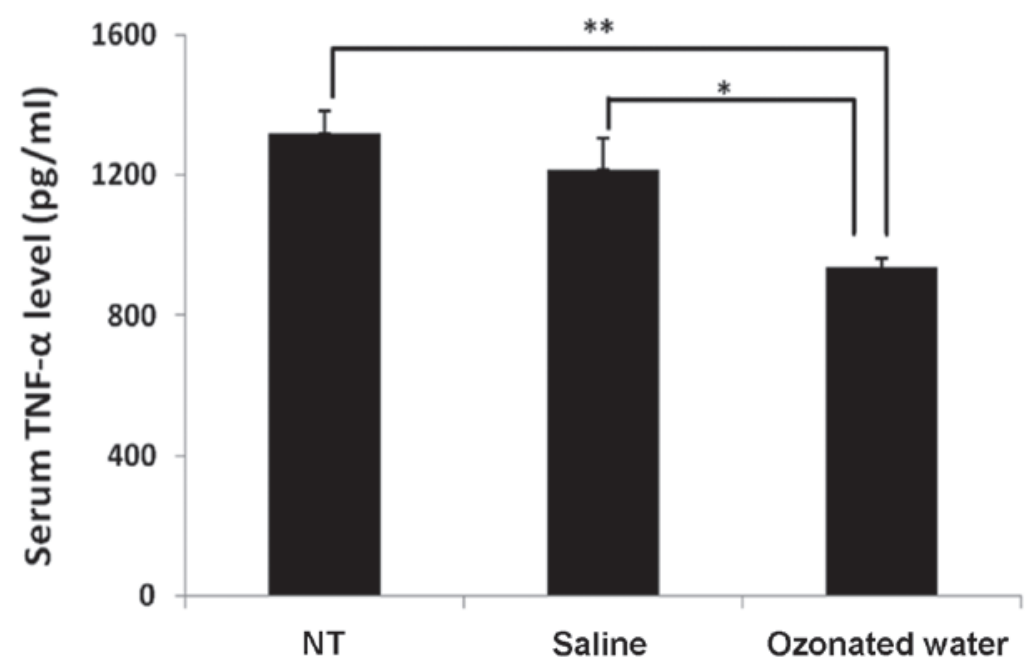

Figure 2. Effect of ozonated water on serum tumor necrosis factor- $\alpha$ (TNF- $\alpha$ ) level during lipopolysaccharide-evoked acute inflammation. Data are the mean \pm standard error; $n=3$ in each group. ${ }^{* *} \mathrm{P}<0.01$ compared to the non-treatment (NT) group, ${ }^{*} \mathrm{P}<0.05$ compared to the saline group. Statistical analyses were carried out using the Tukey-Kramer test.

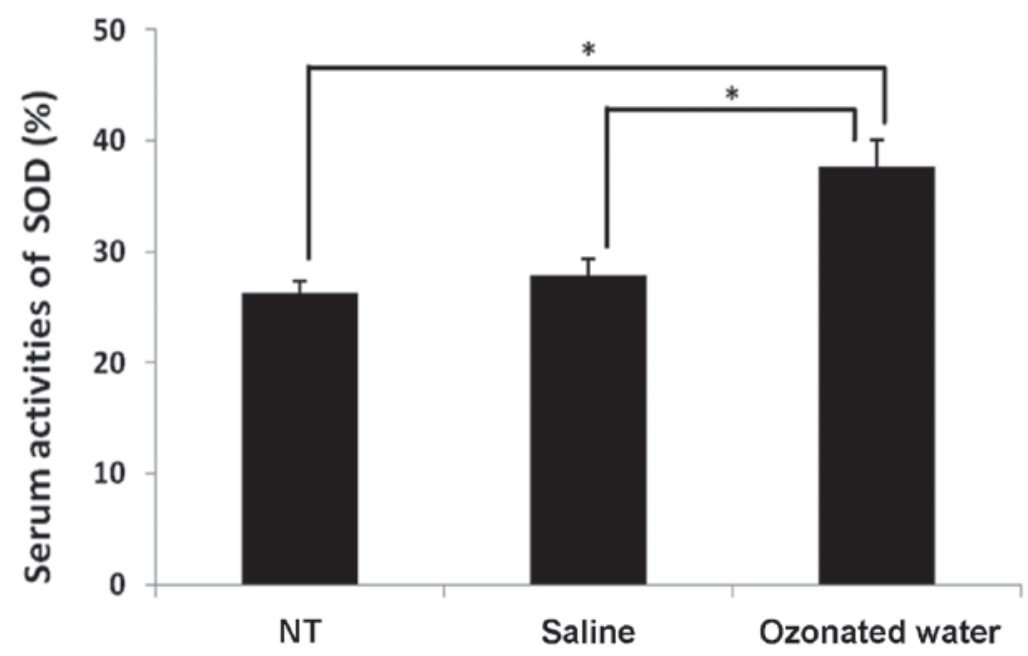

Figure 3. Effect of ozonated water on superoxide dismutase (SOD) serum activity during lipopolysaccharide-induced acute inflammation. Data are the mean \pm standard error; $n=3$ in each group. ${ }^{*} \mathrm{P}<0.05$ compared to the non-treatment (NT) group. Values were calculated using the Tukey-Kramer test. 
randomized into 3 groups: non-treatment $(\mathrm{NT})(\mathrm{n}=3)$, control $(n=3)$ and ozonated water-treated group $(n=3)$. The control and ozonated water-treated group mice were injected with $1 \mathrm{ml}$ of saline or the ozonated water $(10 \mathrm{ppm})$ intraperitoneally every $24 \mathrm{~h}$ for 5 days. LPS (Wako Co., Ltd., Osaka, Japan) was dissolved into saline $(0.2 \mathrm{mg} / \mathrm{ml})$. Twenty-four hours after the last injection of saline or ozonated water, all nine mice were injected $1 \mathrm{mg} / \mathrm{kg}$ LPS intraperitoneally. After $1 \mathrm{~h}$, the mice were sacrificed and blood samples were collected. The blood serum was separated by centrifugation at $500 \mathrm{x}$ g for $10 \mathrm{~min}$ at $4^{\circ} \mathrm{C}$ and the sera were stored at $-80^{\circ} \mathrm{C}$ for subsequent analysis.

Tumor necrosis factor- $\alpha(\mathrm{TNF}-\alpha)$ was quantified by a sandwich enzyme-linked immunosorbent assay (ELISA) using a commercial mouse TNF- $\alpha$ ELISA kit (Quantikine ${ }^{\circledR}$; R\&D Systems, Inc., Minneapolis, MN, USA). SOD activity was evaluated using the nitroblue tetrazolium dye test (Wako Co., Ltd.). The two measurements were performed according to the manufacturer's instructions.

Statistical analysis. Data were expressed as mean \pm standard error. Statistical analysis was performed using one-way analysis of variance followed by the Tukey-Kramer test. $\mathrm{P}<0.05$ was considered to indicate a statistically significant difference.

\section{Results}

Measurement of the half-life of the dissolved ozone. Changes in the concentration of dissolved ozone at $27^{\circ} \mathrm{C}$ are shown in Fig. 1. The concentrations of dissolved ozone decreased constantly and lineally. We also found that the half-life of the dissolved ozone was $36.8 \pm 2.7 \min \left(27^{\circ} \mathrm{C}, \mathrm{n}=4\right)$.

Protective effect of ozonated water on LPS-induced acute inflammation. The TNF- $\alpha$ levels are shown in Fig. 2. In the ozonated water-treated group, the level of TNF- $\alpha(935 \pm 87 \mathrm{pg} / \mathrm{ml})$ in the serum was significantly lower than the levels in the NT $(935 \pm 87 \mathrm{pg} / \mathrm{ml})$ and saline-treated $(935 \pm 87 \mathrm{pg} / \mathrm{ml})$ groups $(\mathrm{P}<0.01$ vs. $\mathrm{NT}$ and $\mathrm{P}<0.05$ vs. saline group).

Effect of ozonated water on superoxide dismutase (SOD) serum activity. The serum SOD activity is shown in Fig. 3. In the ozonated water-treated group, SOD activity $(38 \pm 2 \%)$ was significantly higher than that in the NT $(26 \pm 1 \%)$ and saline-treated $(28 \pm 1 \%)$ groups $(\mathrm{P}<0.05$, vs. the NT and saline groups).

\section{Discussion}

Oxidative damage to vital cellular molecules and structures such as DNA, lipids, proteins and membranes is induced by ROS (23). The mitochondrial electron transport chain is a major source of intracellular ROS and is susceptible to damage initiated by ROS (24). ROS potentially induces cellular antioxidant defense enzymes, including SOD (25). Previously, it has been shown that exposure to LPS increases circulating neutrophils (26) leading to systemic oxidative stress (27). Tissue neutrophils, macrophages and monocytes secrete inflammatory cytokines including TNF- $\alpha(28,29)$. Previous reports indicate $\mathrm{O}_{3}$ has strong antioxidant activities $(4,5)$. In the present study, the serum level of TNF- $\alpha$ and SOD serum activity were signifi- cantly decreased and increased, respectively, in the ozonated water-treated compared to the other groups. Inflammatory cytokines, including TNF- $\alpha$, are major mediators of inflammation in peritonitis (30). Since $\mathrm{O}_{3}$ therapy induces oxidation in the body, the activities of antioxidant enzymes such as SOD are increased subsequent to $\mathrm{O}_{3}$ treatment $(5,31)$. In the experimental septic rat model, the therapeutic effect of $\mathrm{O}_{3}$ treatment in the rectum was confirmed (32). Our results show the ozonated water also exhibit antioxidative and anti-inflammatory activities. Previous studies indicate ROS was produced following endotoxin shock-activated nuclear factor (NF)- $\kappa \mathrm{B}$ and increased the production of inflammatory cytokines (33-35). Overexpression of SOD suppresses TNF- $\alpha$ production in human breast cancer cells (36). Our findings may indicate that ozonated water increased the activation of SOD, which decreased ROS levels. However, additional studies should be performed to gain an understanding of the mechanism involved in the anti-inflammatory effects of ozonated water.

In conclusion, our results have shown that ozonated water exerts critical anti-inflammatory effects. In addition, ozonated water is useful as a therapeutic option for acute inflammation.

\section{References}

1. Burns DT: Early problems in the analysis and the determination of ozone. Fresenius J Anal Chem 357: 178-183, 1997.

2. Bocci V, Zanardi I and Travagli V: Has oxygen-ozonetherapy a future in medicine? J Exp Integr Med 1: 5-11, 2011.

3. Bocci V: Ozone as Janus: this controversial gas can be either toxic or medically useful. Mediators Inflamm 13: 3-11, 2004.

4. Bocci V: Is it true that ozone is always toxic? The end of a dogma. Toxicol Appl Pharmacol 216: 493-504, 2006.

5. Bocci V: Does ozone therapy normalize the cellular redox balance? Implications for therapy of human immunodeficiency virus infection and several other diseases. Med Hypotheses 46: 150-154, 1996.

6. Lippmann M: Health effects of ozone. A critical review. JAPCA 39: 672-695, 1989.

7. Devlin RB, McDonnell WF, Mann R, Becker S, House DE, Schreinemachers D and Koren HS: Exposure of humans to ambient levels of ozone for 6.6 hours causes cellular and biochemical changes in the lung. Am J Respir Cell Mol Biol 4: 72-81, 1991

8. Aris RM, Christian D, Hearne PQ, Kerr K, Finkbeiner WE and Balmes JR: Ozone-induced airway inflammation in human subjects as determined by airway lavage and biopsy. Am Rev Respir Dis 148: 1363-1372, 1993.

9. Krishna MT, Madden J, Teran LM, Biscione GL, Lau LC, Withers NJ, Sandstrom T, Mudway I, Kelly FJ, Walls A, et al: Effects of $0.2 \mathrm{ppm}$ ozone on biomarkers of inflammation in bronchoalveolar lavage fluid and bronchial mucosa of healthy subjects. Eur Respir J 11: 1294-1300, 1998.

10. Broeckaert F, Arsalane K, Hermans C, Bergamaschi E, Brustolin A, Mutti A and Bernard A: Lung epithelial damage at low concentrations of ambient ozone. Lancet 353: 900-901, 1999.

11. Bell ML, McDermott A, Zeger SL, Samet JM and Dominici F: Ozone and short-term mortality in 95 US urban communities, 1987-2000. JAMA 292: 2372-2378, 2004.

12. Tager IB, Balmes J, Lurmann F, Ngo L, Alcorn S and Kunzli N: Chronic exposure to ambient ozone and lung function in young adults. Epidemiology 16: 751-759, 2005.

13. Soulage C, Perrin D, Cottet-Emard JM, Pequignot J, Dalmaz Y and Pequignot JM: Central and peripheral changes in catecholamine biosynthesis and turnover in rats after a short period of ozone exposure. Neurochem Int 45: 979-986, 2004.

14. Ruidavets JB, Cournot M, Cassadou S, Giroux M, Meybeck M and Ferrieres J: Ozone air pollution is associated with acute myocardial infarction. Circulation 111: 563-569, 2005.

15. Bell ML, Dominici F and Samet JM: A meta-analysis of time-series studies of ozone and mortality with comparison to the national morbidity, mortality, and air pollution study. Epidemiology 16: 436-445, 2005. 
16. Ito K, De Leon SF and Lippmann M: Associations between ozone and daily mortality: analysis and meta-analysis. Epidemiology 16: 446-457, 2005.

17. Levy JL, Chemerynski SM and Sarnat JA: Ozone exposure and mortality: an empiric bayes metaregression analysis. Epidemiology 16: 458-468, 2005.

18. Bates DV: Ambient ozone and mortality. Epidemiology 16: 427-429, 2005

19. Goodman SN: The methodologic ozone effect. Epidemiology 16: 430-435, 2005

20. Scott DB and Lesher EC: Effect of ozone on survival and permeability of Escherichia coli. J Bacteriol 85: 567-576, 1963.

21. Restaino L, Frampton EW, Hemphill JB and Palnikar P: Efficacy of ozonated water against various food-related microorganisms. Appl Environ Microbiol 61: 3471-3475, 1995.

22. Ozmen V, Thomas WO, Healy JT, Fish JM, Chambers R, Tacchi E, Nichols RL, Flint LM and Ferrara JJ: Irrigation of the abdominal cavity in the treatment of experimentally induced microbial peritonitis: efficacy of ozonated saline. Am Surg 59: 297-303, 1993.

23. Cadet J, Bellon S, Douki T, Frelon S, Gasparutto D, Muller E, Pouget JP, Ravanat JL, Romieu A and Sauvaigo S: Radiation-induced DNA damage: formation, measurement, and biochemical features. J Environ Pathol Toxicol Oncol 23: 33-43, 2004.

24. Murphy MP: How mitochondria produce reactive oxygen species. Biochem J 417: 1-13, 2009.

25. Turrens JF: Mitochondrial formation of reactive oxygen species. J Physiol 552: 335-344, 2003.

26. Zhang B, Su Y, Ai G, Wang Y, Wang T and Wang F: Involvement of peroxiredoxin I in protecting cells from radiation-induced death. J Radiat Res 46: 305-312, 2005.

27. Cheah FC, Jobe AH, Moss TJ, Newnham JP and Kallapur SG: Oxidative stress in fetal lambs exposed to intra-amniotic endotoxin in a chorioamnionitis model. Pediatr Res 63: 274-279, 2008.
28. Lin HI, Chu SJ, Wang D and Feng NH: Pharmacological modulation of TNF production in macrophages. J Microbiol Immunol Infect 37: 8-15, 2004.

29. Zamora ZB, Borrego A, Lopez OY, Delgado R, Gonzalez R, Menendez S, Hernandez F and Schulz S: Effects of ozone oxidative preconditioning on TNF-alpha release and antioxidant-prooxidant intracellular balance in mice during endotoxic shock. Mediators Inflamm 2005: 16-22, 2005.

30. Beutler B and Cerami A: The biology of cachectin/TNF - a primary mediator of the host response. Annu Rev Immunol 7: 625-655, 1989.

31. Peralta C, Leon OS, Xaus C, Prats N, Jalil EC, Planell ES, Puig-Parellada P, Gelpi E and Rosello-Catafau J: Protective effect of ozone treatment on the injury associated with hepatic ischemia-reperfusion: antioxidant-prooxidant balance. Free Radic Res 31: 191-196, 1999.

32. Souza YM, Fontes B, Martins JO, Sannomiya P, Brito GS, Younes RN and Rasslan S: Evaluation of the effects of ozone therapy in the treatment of intra-abdominal infection in rats. Clinics (Sao Paulo) 65: 195-202, 2010.

33. Chandel NS, Trzyna WC, McClintock DS and Schumacker PT: Role of oxidants in NF-kappa B activation and TNF-alpha gene transcription induced by hypoxia and endotoxin. J Immunol 165: 1013-1021, 2000.

34. Gilmore TD: The Rel/NF-kappaB signal transduction pathway: introduction. Oncogene 18: 6842-6844, 1999.

35. Nakamura H, Nakamura K and Yodoi J: Redox regulation of cellular activation. Annu Rev Immunol 15: 351-369, 1997.

36. Manna SK, Zhang HJ, Yan T, Oberley LW and Aggarwal BB: Overexpression of manganese superoxide dismutase suppresses tumor necrosis factor-induced apoptosis and activation of nuclear transcription factor-kappaB and activated protein-1. J Biol Chem 273: 13245-13254, 1998. 